\title{
Populational approach in ecophysiological studies: the case of Plathymenia reticulata, a tree from Cerrado and Atlantic Forest
}

\author{
José Pires de Lemos Filho" ${ }^{*}$, Maíra Figueiredo Goulart ${ }^{2,3}$ and Maria Bernadete Lovato ${ }^{4}$
}

${ }^{1}$ Departamento de Botânica, Universidade Federal de Minas Gerais, Av. Antônio Carlos 6627, 31270-010, Belo Horizonte, MG, Brasil. ${ }^{2}$ Departamento de Ciências Biológicas, Universidade Federal dos Vales do Jequitinhonha e Mucuri, Rua da Glória 187, 39100-000, Diamantina, MG, Brasil. ${ }^{3}$ Instituto Biotrópicos de Pesquisa em Vida Silvestre, Rua Rio Grande 219, 39100-000, Diamantina, MG, Brasil. ${ }^{4}$ Departamento de Biologia Geral, Universidade Federal de Minas Gerais, Av. Antônio Carlos 6627, 31270-010, Belo Horizonte, MG, Brasil. *Corresponding author: lemos@icb.ufmg.br

Received: 1 October 2008; Accepted: 11 November 2008

The variability of ecophysiological traits among populations can be a result of selection in response to environmental pressure and/or due to random factors, like the genetic drift. The analysis of both genetic and phenotypic variation within populations can lead to better understanding of adaptation in order to colonize different habitats. In the last years we have developed several studies with an widely ecogeographic distributed legume tree species, Plathymenia reticulata, which were focused on identifying specific morphological and physiological traits related to adaptation to the habitats of origin of each studied population. We studied populations from Atlantic Forest, Cerrado and ecotonal sites in relation to phenology, seed morphological traits and their relation with seed dispersion, seed dormancy and germination, and growth traits in a common garden experiment. In several analyzed traits we found high diversity in this species that can explain its occurrence in a broad geographical range. The existence of genetically based differences of traits in an adaptive way among savanna and forest populations suggests a degree of divergence that characterizes the existence of ecotypes from Cerrado and Atlantic Forest. We also pointed future perspectives in studies at population level in evolutionary ecophysiology and implications of these studies for flora conservation and habitat restoration. Key words: Ecotypes, evolutionary ecophysiology, intraspecific variation, local adaptation

\begin{abstract}
Abordagem populacional em estudos ecofisiológicos: o caso de /Plathymenia reticulata/, uma árvore do Cerrado e da Mata Atlântica: A variação em características ecofisiológicas entre populações pode ser devido ao resultado da seleção em resposta a pressão ambiental e/ou pode ser devido a fatores aleatórios como a deriva genética. A análise tanto da variação genética quanto da variação fenotípica das populações, pode levar ao melhor conhecimento sobre adaptações necessárias para a ocupação de diferentes ambientes. Nos últimos anos, nós temos desenvolvido diversos estudos com populações de Plathymenia reticulata, uma leguminosa arbórea de ocorrência em ampla extensão ecogeográfica, com o objetivo de identificar características morfológicas e fisiológicas envolvidas na adaptação das populações aos seus ambientes de origem. Populações provenientes da Mata Atlântica, do Cerrado e de áreas ecotonais entre estes biomas foram avaliadas em relação à fenologia, morfologia e germinação de sementes, bem como em relação à características de crescimento de plantas cultivadas em um mesmo ambiente experimental. Em muitas das características analisadas nessa espécie foi encontrada grande diversidade, o que poderia explicar a sua ocorrência em uma ampla extensão geográfica. A existência de diferenças genéticas em características na direção adaptativa entre as populações provenientes de ambientes de savana e florestais sugere a existência de ecótipos de Cerrado e de Mata Atlântica. Nós também apontamos perspectivas futuras para estudos de ecofisiologia evolutiva em nível populacional, bem como implicações desta abordagem para a conservação da flora e restauração de ambientes.
\end{abstract}

Palavras-chave: Ecótipo, ecofisiologia evolutiva, variação intraespecífica, adaptação local 


\section{INTRODUCTION}

The Atlantic Forest and the Cerrado biomes are included among the most diverse and endangered areas of the world. They have been considered two of the 34 hotspots for biodiversity conservation in a global context (Mittermeier et al., 2004). The existence of great floristic and physiognomic differences between Cerrado and Atlantic Forest suggest that there are also significant differences in ecophysiological traits between their endemic species. Differences in ecophysiological traits between species may have evolved in past environmental conditions, and so may not be easily related to present conditions. However, these differences could indicate habitat preference and nowadays studies have been conducted taking into account the historical relationships between species including their phylogenetic relationships in order to determine traits that result in success on different habitats. Comparative evaluations using phylogenetic independent contrasts (PICs) have being done by Hoffmann and Franco (2003), Hoffmann et al. (2004), Hoffmann et al. (2005). These authors used congeneric tree species from savanna and forest to explain the habitat preference and the forest-savanna boundary dynamics. The same approach was used by Duarte et al. (2005) in a comparative study with shrubs species from different communities at the periphery of Atlantic Forest in order to answer questions about ecophysiological behavior of generalist and specialist species and about adaptations to site characteristics that have occurred irrespective of the taxonomic affiliation of the studied species.

In addition to the use of phylogenetically related species in order to understanding the differences in ecophysiological traits associated to adaptation to different habitats, another approach is the comparison among populations of the same species. This approach has the additional advantage that related populations of the same species will have more genetic affinities and any differences will be more likely to be related to present conditions (Bradshaw, 2006). Populational approach in ecophysiological studies considers the differences between individuals, which is condition for the operation of natural selection (Bazzaz, 1996). In the same way, Lüttge and Scarano (2004) also emphasized the importance of taking into account the intra-specific variability in ecophysiological studies, including phenotypic plasticity and its importance on the development of new species. Phenotypic plasticity, usually defined as the property of genotypes of exhibiting different phenotypes in different environments, could delay speciation due to the protection of genotypes from a specific environmental pressure. It also could allow diversification in species that present an extensive ecological range resulting in specialized genotypes in particular habitats, the ecotypes. Phenotypic plasticity can be adaptive, improving the plant survival and reproduction, or not, due to biochemical, physiological and developmental constraints (Pigliucci et al., 2006).

The variability of ecophysiological traits among populations in some way can be a result of selection in response to environmental pressure and/or can be due to random factors, i.e. genetic drift. The analysis of both, genetic and phenotypic variation within populations can lead to better understanding of adaptation in direction to the occupying of different habitats. Genetic studies using molecular markers in natural populations of neotropical species have showed high intra-specific genetic variation mainly for widely distributed ones (e.g., Lacerda et al., 2001, Ramos et al., 2007, Silva et al., 2007). However, the genetic variation accessed by molecular markers is preferentially neutral and can not reflect variation in morphological and physiological characters. Moreover, it has been shown that populations with almost undetectable molecular variation can show variation in quantitative traits due to high level of phenotypic plasticity (Noel et al., 2007).

Considering all these aspects, in the last years we have developed several ecophysiological studies with a widely ecogeographic distributed tree species, Plathymenia reticulata, in order to identify specific morphological and physiological traits related to adaptation to different characteristics of origin habitats of the populations and understand the evolution of these traits. Overall results and its consequences for the understanding of traits that permit the distribution of this species across the Atlantic Forest and the Cerrado biomes are presented in the next topics.

\section{THE PLATHYMENIA GENUS: NATURAL HISTORY AND TAXONOMIC ASPECTS}

Plathymenia (Leguminosae-Mimosoideae) is a tree genus native from South America that occurs mainly in Brazil but also in other countries such as Bolivia, Paraguay and Surinam (Warwick and Lewis, 2003). It was 
firstly described by Bentham in 1842 with two species ( $P$. reticulata and $P$. foliolosa). Bentham considered the first one to occur in savannas from Cerrado biome and the second in forest physiognomies and forest biomes. During the past century, some taxonomic changes in the Plathymenia genus have been proposed, as the recognition of a third species and varieties (Heringer, 1956; Warwick and Lewis, 2003). However, the most recent taxonomic revision of the genus (Warwick and Lewis, 2003) demonstrated that the main characters used to distinguish $P$. reticulata from $P$. foliolosa, as size, inflorescence indumentum, numbers of pinnae per leaf and leaflets per pinna, occur in a continuum and consequently only $P$. reticulata was retained. This last taxonomic change had the support of the molecular data reported one year before by Lacerda et al. (2002). In that work, populations in areas of Cerrado and Atlantic Forest were evaluated using RAPD (Random Amplified Polymorphic DNA) markers, which showed that $60 \%$ of molecular variation was due to differences among plants from the different biomes. In spite of that, a population located in an ecotonal region between the biomes showed intermediate genetic pattern which was considered as a possible evidence of gene flow between them (Figure 1).

Individuals of $P$. reticulata in forest sites reach 15 to $30 \mathrm{~m}$ in height and more than $70 \mathrm{~cm}$ in trunk diameter while the ones from savanna vegetation in Cerrado are usually shorter and tortuously branched, measuring 6 to 12 meters high and 30 to $50 \mathrm{~cm}$ in trunk diameter (Lorenzi, 1992). In spite of these differences in size, individuals from Atlantic Forest and Cerrado have many characteristics in common, as the deciduous habit, the morphology of the flowers and inflorescences, floral visitors as small insects, specially generalists bees, and also fruits characterized as pendent pods, within which seeds are enclosed in a thin membranous endocarp, as a rectangular papery envelop (Warwick and Lewis, 2003; Silva Jr., 2005). This species is popular known as "vinhático" a name that refers to the "red-wine" color of the tree trunk (Silva Jr., 2005). The high quality wood of $P$. reticulata has many human uses, being pointed as one of the most important and useful plant species of the Cerrado (Almeida et al., 1998). This species is also useful in the recovery of degraded areas (Lorenzi et al., 1992) and in popular medicine (Silva Jr., 2005).

\section{PHENOLOGY}

Phenology is considered a very important component of plant fitness as time of flowering and fruiting strongly influence reproductive success (Marquis, 1988) and leaf fall and flushing are intimately related to growth, water status and gas exchange (Reich, 1995). The populations of $P$. reticulata provide a model to compare phenology among sites characterized by environmental differences, which is very important to understand the extent of phenological variability as a survival strategy in different environments and how abiotic factors influence phenological patterns.

A study conducted with monthly evaluation of 183 individuals following a three-level perspective (populations, habitats and biomes) has shown that most of the phenological asynchrony in this species is due to differences among individuals within populations (Table 1) (Goulart et al., 2005). Asynchrony among individuals may reflect population flexibility, as the adaptation of

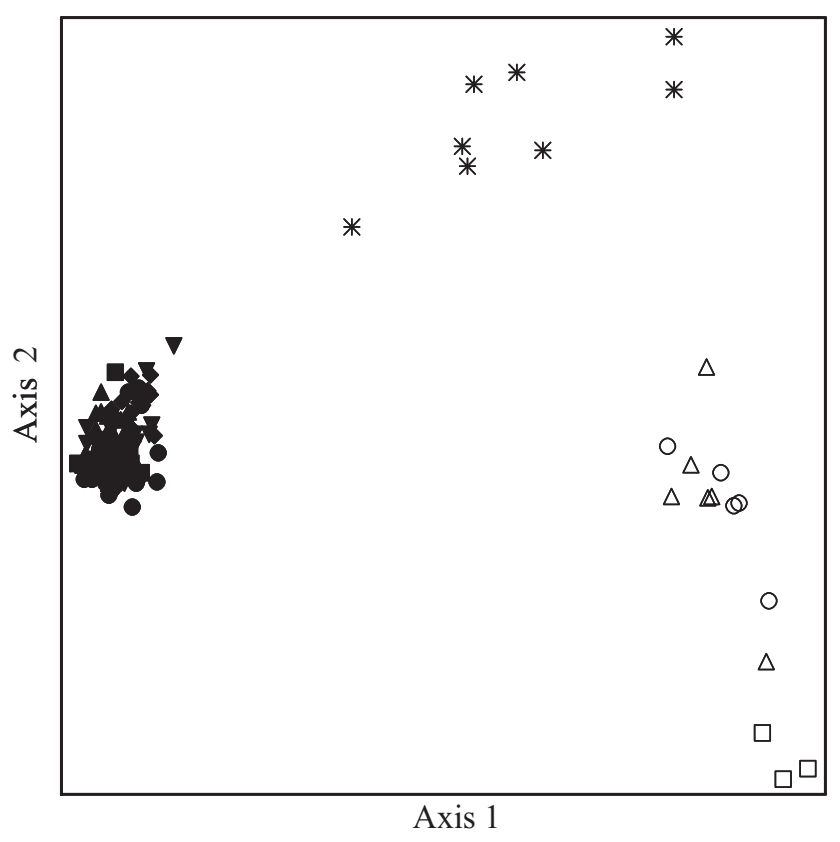

Figure 1. Diagram of Principal Component Analysis with 71 polymorphic RAPD markers, evaluating 138 individuals of $P$. reticulata from different populations from Cerrado (black symbols), Atlantic Forest (white symbols) and from a population with Atlantic Forest characteristics but located in an ecotone between the two biomes (asteristics). Location, characteristics of the populations and detailed methodology are described in Lacerda et al. (2002). 
individuals to a variety of conditions should contribute to population maintenance and expansion (Seghieri and Simier, 2002). In this study, partitioning of the diversity of phenological patterns showed that only about $10 \%$ of the total diversity was due to differences between individuals from Atlantic Forest and Cerrado (Table 1). There is, however, an evident difference among the biomes related to the beginning of the leaf fall, a phenophase that starts earlier in drier areas (Cerrado) and later where the drought period is less severe (Atlantic Forest), while individuals in transitional regions exhibit an intermediate pattern (Figure 2).

\section{SEED DISPERSAL AND GERMINATION}

Seed morphology, dispersal and germination strongly influence the patterns of distribution and abundance of populations and species. Previous studies have demonstrated the existence of significant variation of these traits within and among populations of $P$. reticulata (Lacerda et al., 2004; Goulart et al., 2006).

Individuals within populations are significantly different in at least 13 morphological fruit and seed traits, including seed mass as shown in Figure 3 (Goulart et al., 2006). These differences may be attributed to habitat differences that promote phenotypic variation (Bañuelos and Obeso, 2003; Murray et al., 2003; Murray et al., 2004)

Table 1. Partitioning of phenological diversity in $P$. reticulata obtained with Shannon-Winner diversity index. Data are mean percentages attributable to differences within and among 10 populations, within and among four habitats (Atlantic Forest core, Atlantic Forest ecotone, Cerrado core and Cerrado ecotone) and within and between biomes (Atlantic Forest and Cerrado). Location, characteristics of the populations, vegetative and reproductive phenophases and detailed methodology are described in Goulart et al. (2005).

\begin{tabular}{lcc}
\hline & $\begin{array}{c}\text { Vegetative } \\
\text { phenology }\end{array}$ & $\begin{array}{c}\text { Reproductive } \\
\text { phenology }\end{array}$ \\
\hline Within population & 70 & 60 \\
Among population & 30 & 40 \\
\hline Within habitat & 83 & 83 \\
Among habitat & 17 & 17 \\
\hline Within biome & 91 & 90 \\
Among biome & 9 & 10 \\
\hline
\end{tabular}

or may be caused by random process as genetic drift. However, considering that early life traits are under strong selective pressure, there should also be an adaptive explanation to the variability observed. This explanation may lie on the fact that both larger and smaller seeds have advantages: while the first ones may be advantageous in the germination and recruitment process (Rees, 1996), the second ones are lighter and disperse better with the wind (Yamada and Suzuki, 1999).

There is also considerable variation among individuals within populations concerning seed dormancy (Figure 4). Germination tests showed that at least $84 \%$ of seeds in each population germinated after scarification, demonstrating high viability of seeds and the presence of dormancy imposed by hard and waterimpermeable seed coat. The seed dormancy showed high levels of coefficient of genotypic determination, meaning that a considerable part of the variation in seed dormancy is genetic, rather than environmental (Lacerda et al., 2004). The high genetic diversity within population related to seed dormancy and germination is probably an advantage as it increases the ability to respond to environmental changes, reduce sib competition and also may avoid the simultaneous development of all seedlings when conditions happen to be inadequate (Andersson and Milberg, 1998; Lacerda et al., 2004).

Seed morphological traits and germination also differ between $P$. reticulata populations, although, so far, comparisons between populations located in different biomes approached only morphology but not yet germination (Figures 3 and 4). No significant differences among Atlantic Forest and Cerrado populations were observed in seed mass (Figure 3), however, significant more developed structures associated with wind dispersal were found in Atlantic Forest, while populations from ecotonal regions showed intermediate pattern (Figure 5). Considering that dispersal is not a selectively neutral character (Donohue, 1998), longer seed wings (endocarp envelopes) observed in Atlantic Forest individuals may be due to selective pressure under an environment with a denser leaf cover that diminishes wind. Moreover, a tendency towards lower loading ratios [seed fresh mass/membranous endocarp area, a ratio inversely proportional to the seed dispersal ability (Peroni, 1994)] was observed in Atlantic Forest 
Vegetative phenology
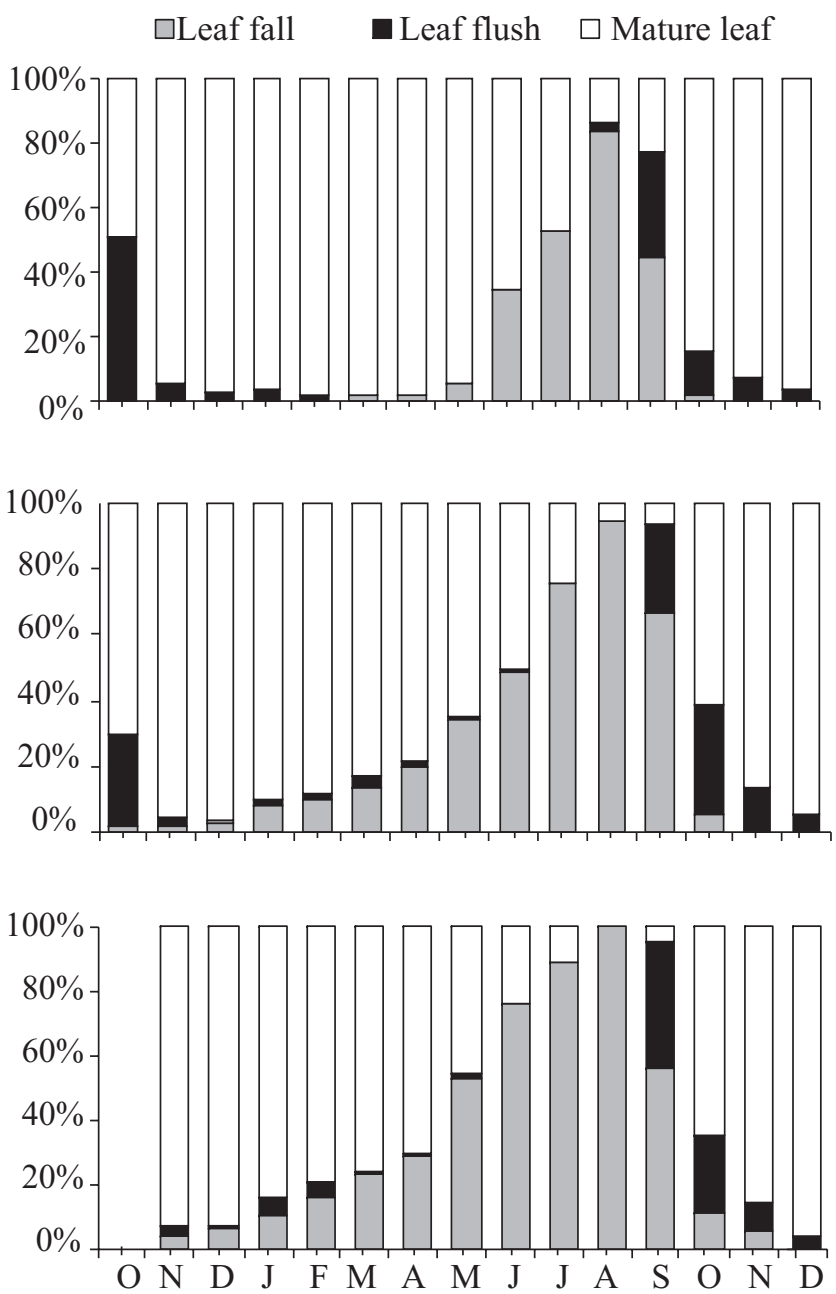

Reproductive phenology

$\square$ Floral bud $\quad$ Flower $\square$ Imature fruit $\square$ Mature fruit

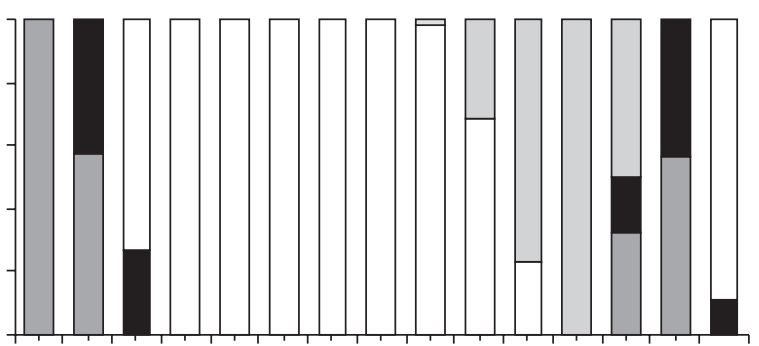

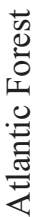

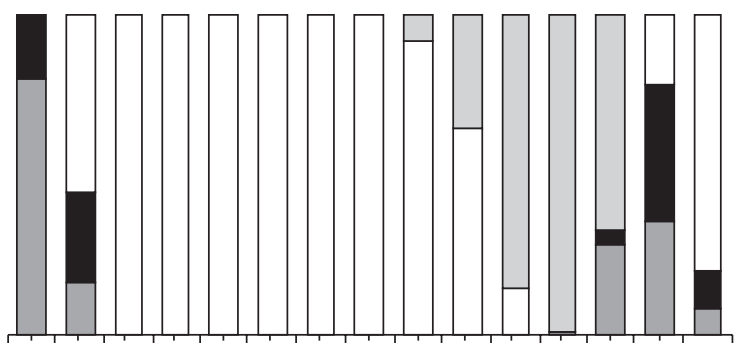

0
0
0
0
0
I

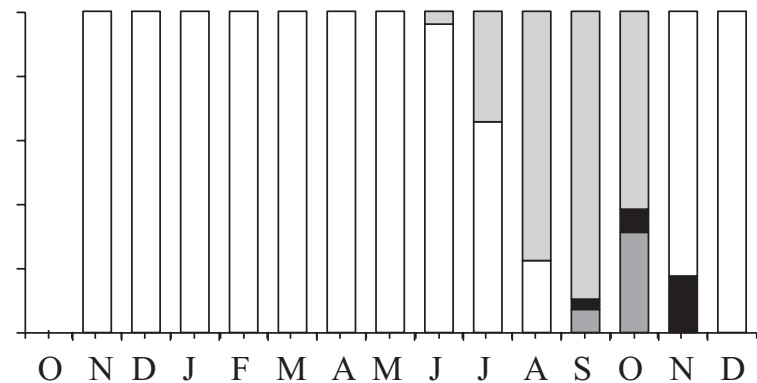

Figure 2. Monthly mean percentages of vegetative and reproductive phenologies found in 182 individuals of $P$. reticulata from populations located in Atlantic Forest, Cerrado and ecotonal region. Location, characteristics of the populations and detailed methodology are described in Goulart et al. (2005).

populations (Figure 5). This means that under the same conditions, forest seeds would tend to show greater dispersal ability when compared to Cerrado ones.

\section{ECOTYPIC DIFFERENTIATION AMONG ATLANTIC FOREST AND CERRADO POPULATIONS}

Ecotypes arise when distinct genetically controlled character states are selected in different populations (Nagy and Rice, 1997), usually colonizing contrasting habitats, for example, in light and nutrients status (Hogan, 1996). In the most recent taxonomic revision of the Plathymenia genus no ecotypes or any infra specific taxa was recognized (Warwick and Lewis, 2003), however, in the previous topics, we discussed that there are differences between Cerrado and Atlantic Forest populations possibly caused by natural selection. Stronger evidences of the existence of different ecotypes adapted to these different environments were observed when seedlings were grown in common garden; these unpublished data will be presented here.

Seedlings from Cerrado, Atlantic Forest and ecotonal populations were grown in pots of $25 \mathrm{~cm}$ of diameter and $40 \mathrm{~cm}$ of depth, filled with 3:1 nutrient enriched peat and sand mixture, placed in three random blocks in a shade 

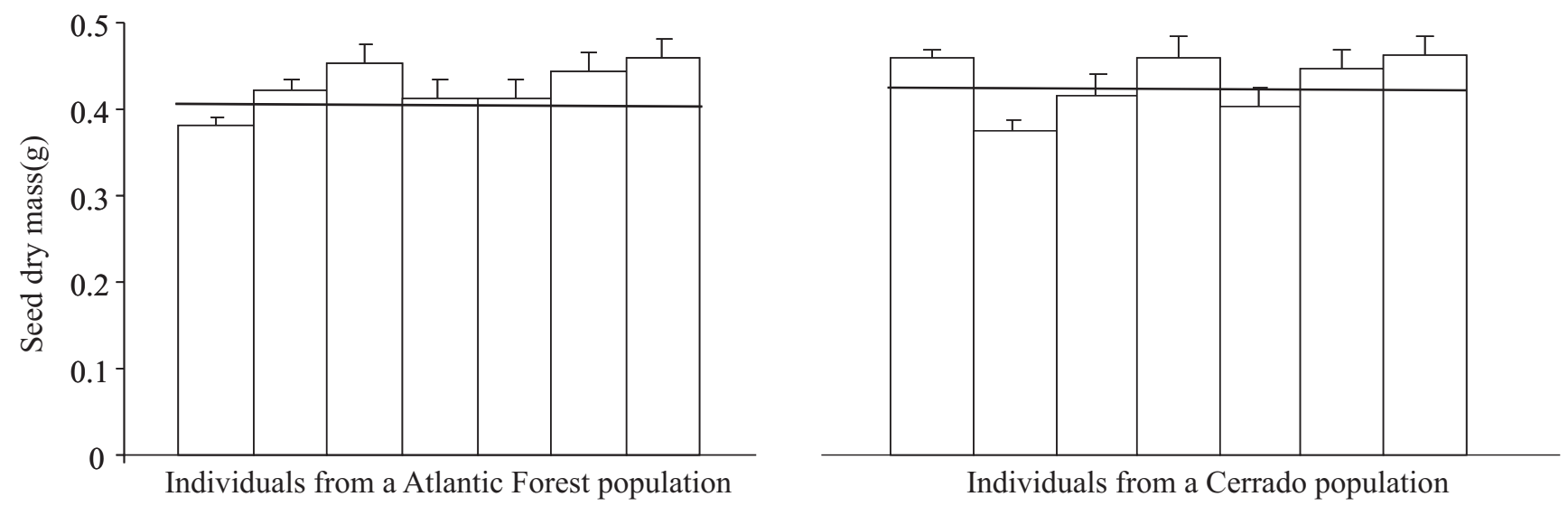

Figure 3. Dry mass of seeds from individual trees of two populations of $P$. reticulata. Bars are means \pm standard deviations obtained for each individual, horizontal lines are population's mean. There are significant differences among individuals within populations (ANOVA, $\mathrm{p}<0.05$ ) but no significant differences among populations (Tukey test, $\mathrm{p}<0.05$ ). Location, characteristics of the populations and detailed methodology are described in Goulart et al. (2005).

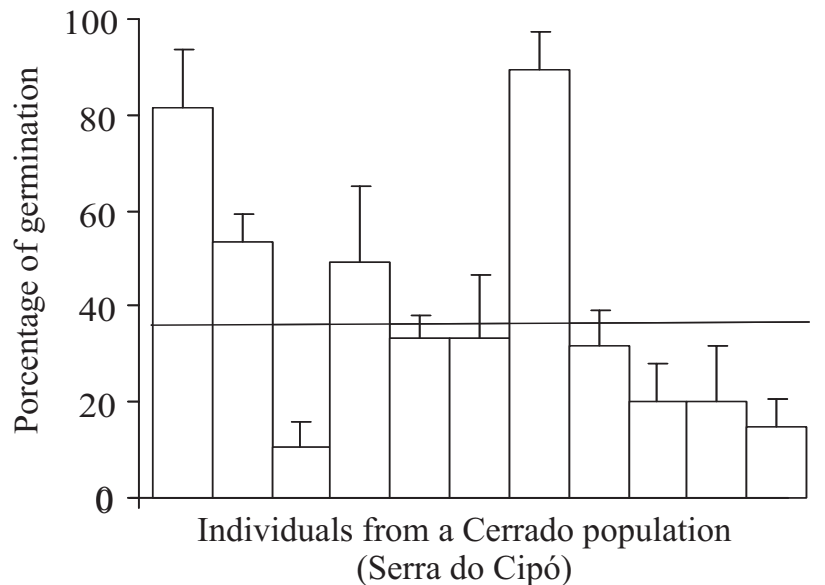

(Serra do Cipó)

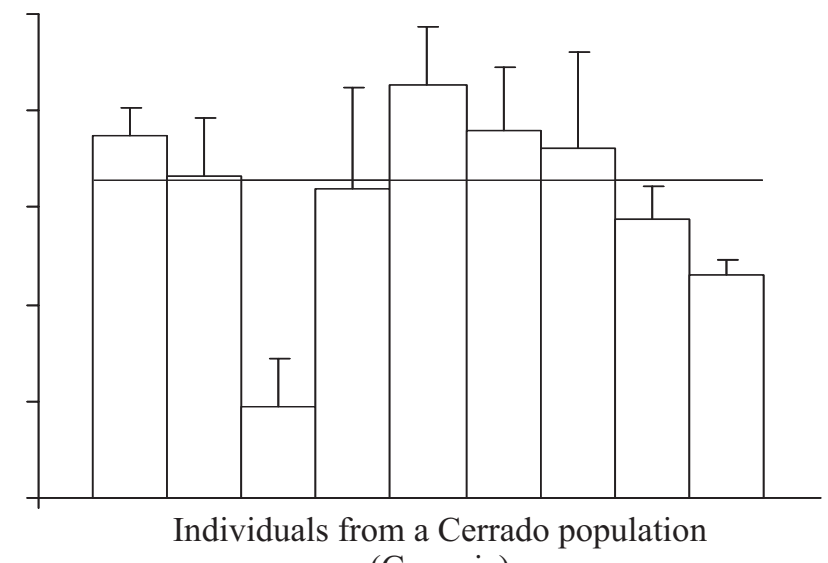

(Gouveia)

Figure 4. Germination of seeds from individual trees of two populations of $P$. reticulata evaluated in the same environmental conditions. Bars are means \pm standard deviations obtained for each individual, horizontal lines are population's mean. There are significant differences among individuals within populations (ANOVA, $p<0.05$ ) as well as significant differences among populations (Tukey test, $\mathrm{p}<0.05$ ). Location, characteristics of the populations and detailed methodology are described in Lacerda et al. (2004).

house that provided about $22 \%$ of full sunlight. During the first six months of growth they were evaluated concerning several morphological traits (Figure 6).

Individuals from Atlantic Forest showed to be more adapted to cope with shade than Cerrado ones as they invested proportionately more in shoot biomass than in root biomass, they also showed higher investment in growing taller and elongating stems, responses known as shade avoidance syndrome (Ballaré et al., 1997; Smith and
Whitelan, 1997; Kurepin et al., 2006). Individuals from Atlantic Forest also showed higher values of relative growth rate, an advantage that may promote quick occupation of the available space within the crowded vegetation (Poorter and Garnier, 2007). On the other hand, individuals from Cerrado showed lower growth rate, a characteristic frequently related to stress resistant syndrome, typically found in plants specialist to lowresource environment (Chapin et al., 1993). It is 

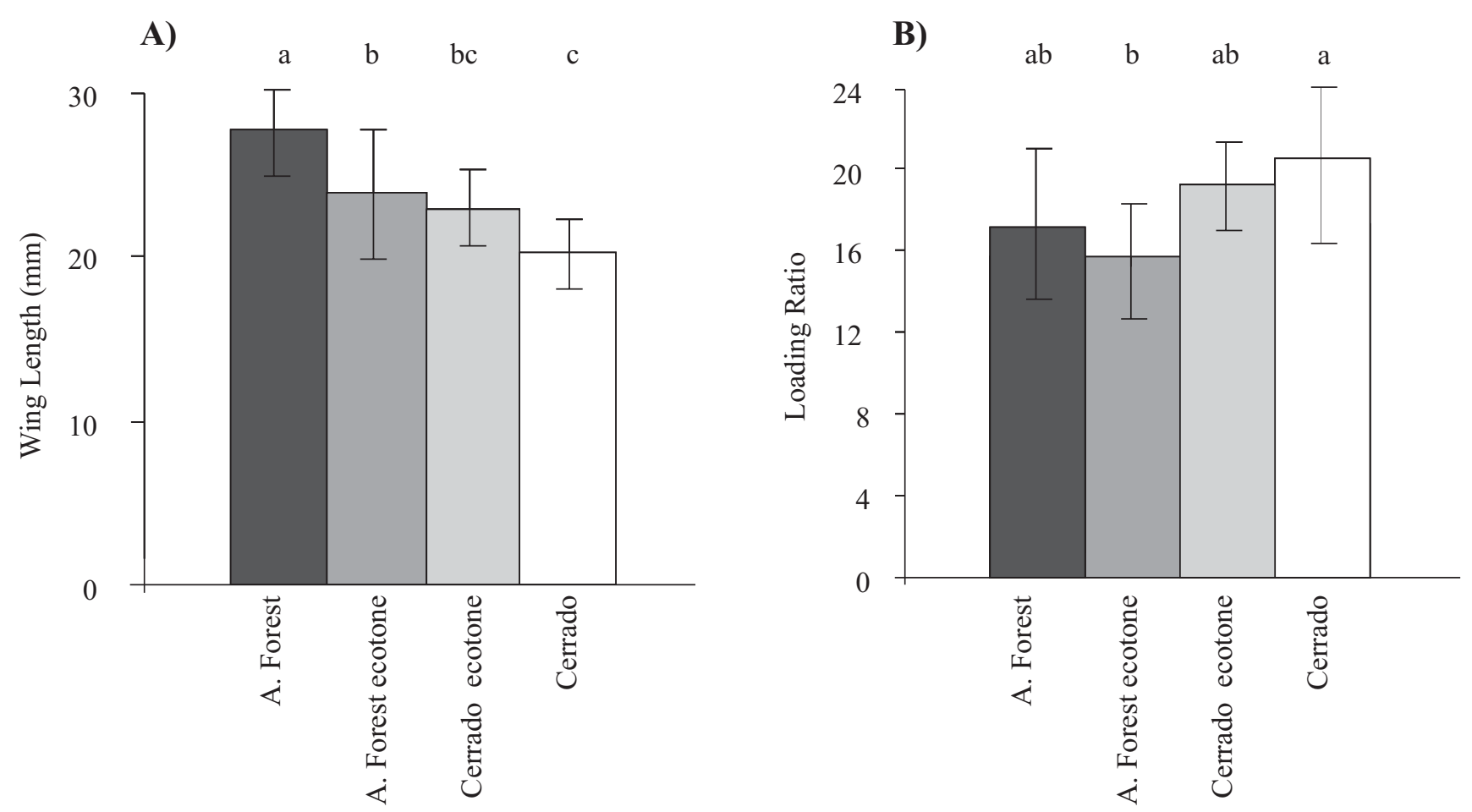

Figure 5. Comparisons among populations of $P$. reticulata from Atlantic Forest and Cerrado core and ecotonal regions, concerning wing length (A) and loading ratio (B). Bars are means \pm standard deviations ( $N=100$ to 200). For both $A$ and $B$ there are significant differences among populations (ANOVA, $\mathrm{p}<0.05$ ); different letters in each graphic indicate significant differences (Tukey test, $\mathrm{p}<0.05$ ). Location, characteristics of the populations and detailed methodology are described in Goulart et al. (2006).

suggested that, by growing slow, plants can accumulate sugar and nutrients during favorable times, enabling them to grow when resources are less available (Poorter and Garnier, 2007). Lower investment in shoots than in roots was found in Cerrado individuals and it may also be related to the stress resistance syndrome. Differences in root and shoot biomass partitioning has being pointed by Hoffmann and Franco (2003) as the most striking difference between Cerrado and Forests species, it is interesting that this difference could also be detected while evaluating a micro-evolutionary process.

The differences found among populations of $P$. reticulata from Atlantic Forest, Cerrado (Figures 6 and 7) show the existence of genetically based differences among these populations occurring in an adaptive direction, which lead us to conclude that there are different ecotypes from savanna and forest in this species. There are reports in the literature suggesting the existence of tree ecotypes adapted to different Cerrado physiognomies (Fuzeto and Lomônaco, 2000; Cardoso and Lomônaco, 2003) and, for other species, ecotypes adapted to different forest types (Stubblebine et al., 1978; Delprete, 1997). However, no ecotypic differentiation for a species occurring in Atlantic Forest and savannas from Cerrado was previously demonstrated.

At the boundary between the biomes, $P$. reticulata populations showed intermediate values for several studied traits (Figure 6). Considering that the studied boundary is characterized by a mosaic of adjacent patches of Cerrado and Atlantic Forest physiognomically very similar to their respective core habitat, it is not likely that the ecotone populations are ecotypes adapted to intermediate environmental conditions. Alternatively, it is more likely that the ecotone populations are characterized by hybrid individuals between ecotypes. Hybridization is possible since there is similar flowering period between populations (Goulart et al., 2005), moreover, evidence of gene flow has been pointed by Lacerda et al. (2002) based on data from neutral genetic markers. 

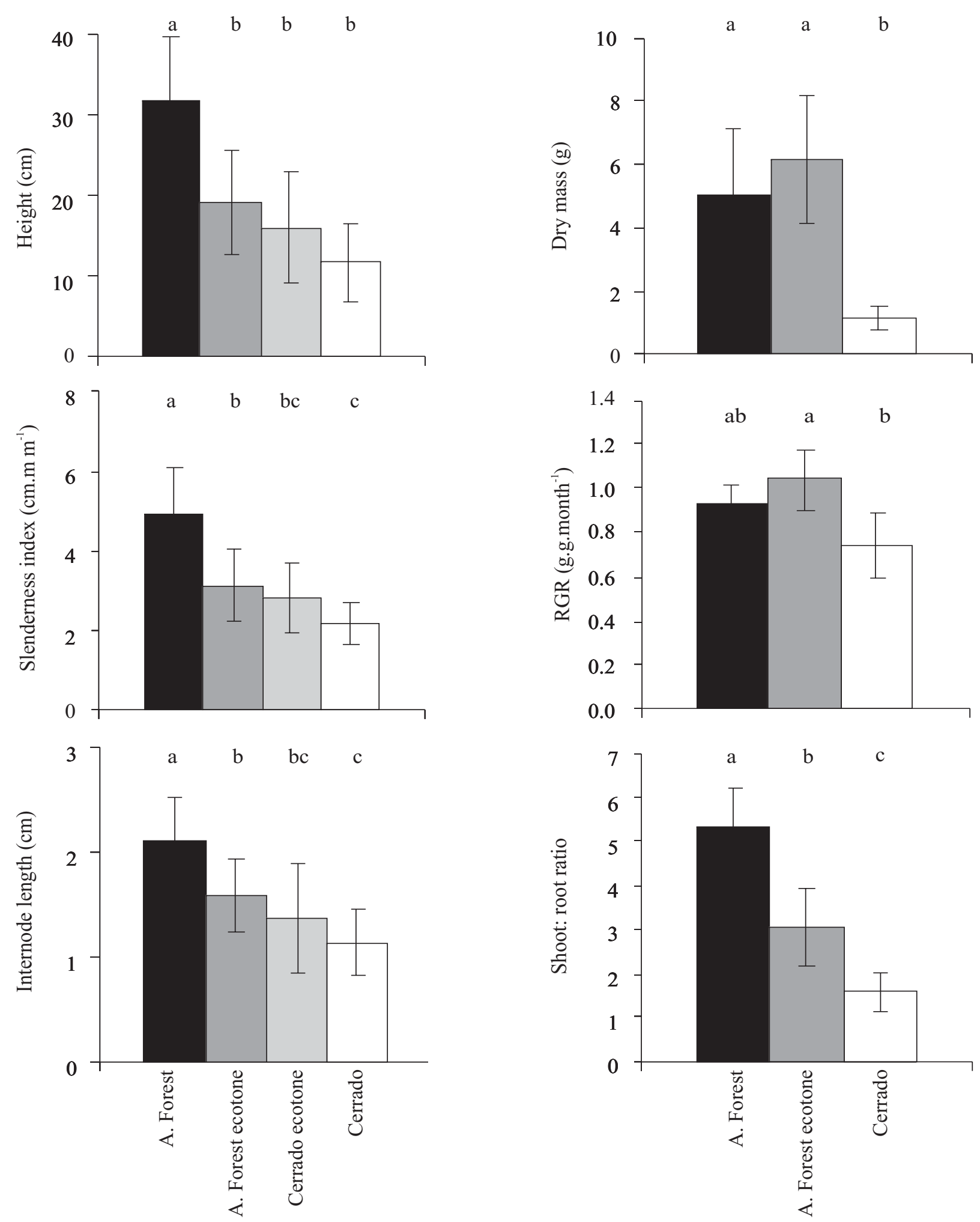

Figure 6. Comparisons among populations of $P$. reticulata from Atlantic Forest and Cerrado core and ecotonal regions obtained in six month saplings, concerning plant maximum height, slenderness index (height/base diameter), internode length (height/number of internodes), total dry mass, relative growth rate (RGR) and shoot:root ratio. Bars are means \pm standard deviations ( $\mathrm{N}=5$ to 10$)$. Different letters in each graphic indicate significant differences (Tukey test, $\mathrm{p}<0.05)$. 

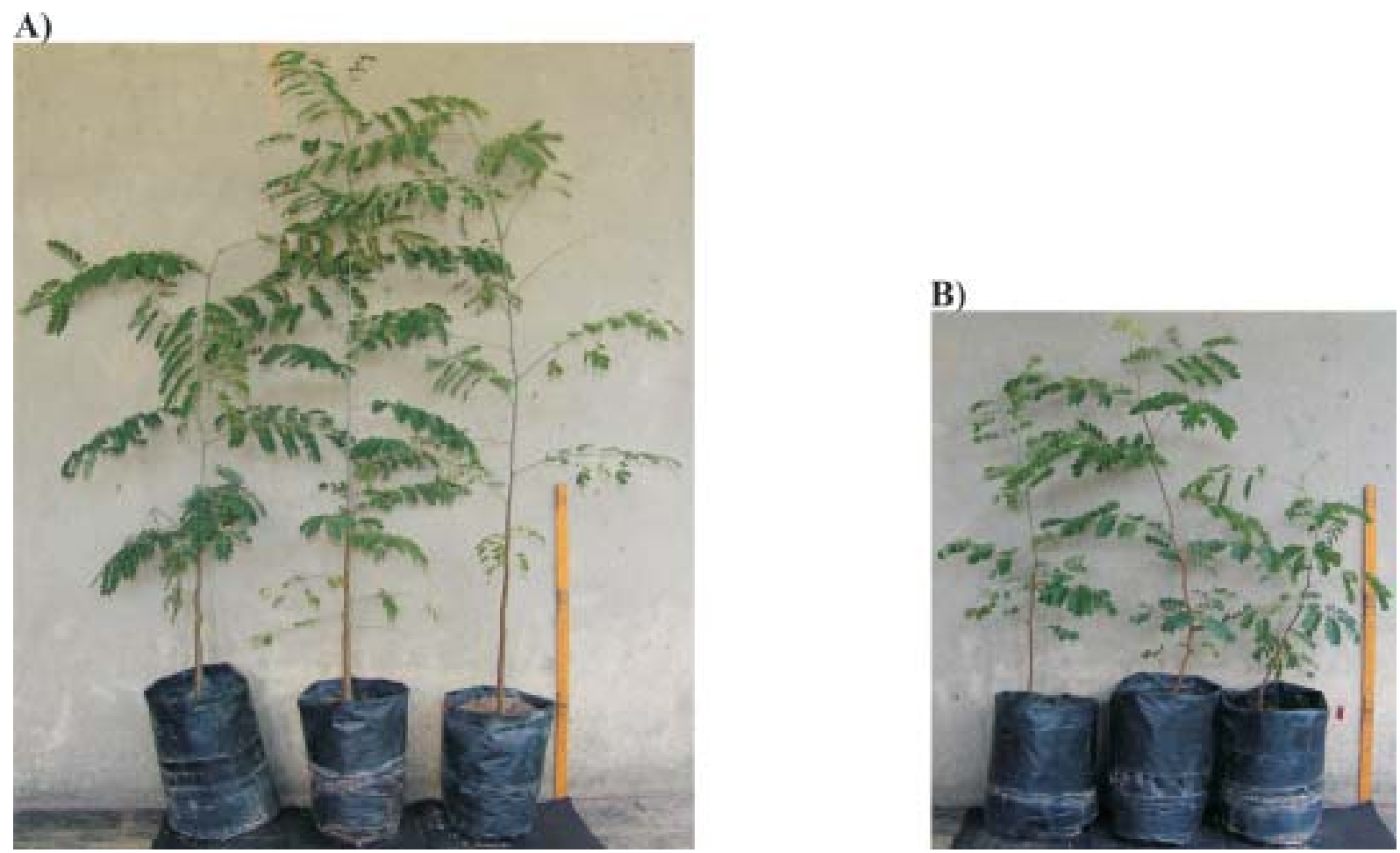

Figure 7. Individuals of $P$. reticulata from Atlantic Forest (A) and Cerrado (B) core regions with 10 months of growth in a common garden condition. Scales on the right of each figure measure $60 \mathrm{~cm}$.

\section{CONCLUDING REMARKS AND FUTURE TRENDS}

There are a lot of data (Goulart et al., 2005; Goulart et al., 2006; the present article) showing adaptative traits on $P$. reticulata populations related to their habitat of origin. The high ecophysiological diversity of this species permits its occurrence in a broad geographical range from Cerrado to Atlantic Forest. The existence of genetically based differences among savanna and forest populations suggests a degree of divergence that characterizes the existence of ecotypes from Cerrado and Atlantic Forest. It is also relevant to point out that in the ecotonal sites is frequent the occurrence of populations that present intermediary behavior in many of the studied traits, that could be explained by the share of genes from both forest and savanna populations. These ecotonal sites provide an interesting material for studies in plant evolution, such as the estimate of the relative influence of gene flow and selection in shaping the evolution in very different environments that characterize Atlantic Forest and Cerrado. In spite of the several studies with $P$. reticulata populations, many other ecophysiological traits can also be evaluated, as drought resistance and thermotolerance, characteristics that are of special relevance in the current discussion of anthropogenic climatic changes.

The basic concept of phenotypic plasticity in genetics and evolutionary biology, the capacity of a genotype to express different phenotypes for a given trait under different environments, nowadays has been expanded in studies of species and populations in their ecological context (see Valladares et al., 2006). In this sensu lato approach, studies comparing responses of progenies from populations in common garden, focusing to evaluate differential response to an environmental factor is particularly relevant for the understanding of the plasticity variation an its ecological evolutionary consequence. With quantitative estimators of plasticity in studies with populations as described by Valladares et al. (2006) it is possible to rank populations according to their phenotypic plasticity in ecophysiological traits, and test hypotheses to understand why these populations exhibit different degrees of plasticity. The capacity of populations to respond to environmental change by 
phenotypic plasticity has been considered an important characteristic to face the increase in the frequency of extreme climatic events related to man-induced global climatic changes (Jump and Peñuelas, 2005). So, the use of quantitative tools to access the phenotypic plasticity as described in Valladares et al. (2006) could be useful in micro-evolutionary studies with a widely ecogeographic distributed species as $P$. reticulata and for other species including those that present a narrow geographic range.

Finally, must be pointed the implications of these evolutionary ecophysiological studies for conservation. Recent concerns in relation to biodiversity conservation and habitats restoration have stressed the importance of identification of evolutionary significant units (ESU) defined as genetically differentiated populations that require separate management (Moritz, 1995). This definition frequently based on only molecular markers have been criticized for several authors, which have stressed the importance in considering also the adaptive differences between populations for identify ESUs (see Crandall et al., 2000). Studies of ecophysiological traits within a populational perspective, as those here showed for Plathymenia reticulata, allow the identification of populations genetically differentiated in traits related to the adaptation to different environments. These populations, commonly designed as ecotypes, constitute different ESUs that should be managed separately, since that admixture of different ESUs through gene flow can break out the adaptive allelic combination and thus lowering the fitness of populations. In species in that ESUs are identified, this aspect should be taken into account in projects of habitat restoration or reintroduction for the success of them not be compromised. These approaches increase the importance of plant evolutionary ecophysiology, providing relevant data for the understanding of the high diversity of tropical biomes and for practices for their conservation and restoration.

Acknowledgments: Data collection was supported by Fundação de Amparo à Pesquisa do Estado de Minas Gerais (FAPEMIG) and by PELD Program of the Conselho Nacional de Desenvolvimento Científico e Tecnológico (CNPq). M.F. Goulart has received fellowship from Coordenação de Aperfeiçoamento de Pessoal de Nível Superior (CAPES) and from CNPq. J. P. Lemos-Filho and M.B. Lovato received a research fellowship from CNPq.

\section{REFERENCES}

Almeida SP, Proença CEB, Sano SM, Ribeiro JF (1998) Cerrado: espécies vegetais úteis. Embrapa-CPAC, Planaltina.

Andersson L, Milberg P (1998) Variation in seed dormancy among mother plants, populations and years of seed collection. Seed Sci. Res. 8:29-38.

Ballaré CL, Scopel AL, Sanchez RA (1997) Foraging for light: photosensory ecology and agricultural implications. Plant Cell Env. 20:820-825.

Bañuelos MJ, Obeso JR (2003) Maternal provisioning, sibling rivalry and seed mass variability in the dioecious shrub Rhammus alpinus. Evol. Ecol. 17:1931.

Bazzaz FA (1996) Plants in changing environments: linking physiological, population and community ecology. Cambridge Univ. Press.

Bradshaw AD (2006) Unravelling phenotypic plasticity why should we bother? New Phytol. 170:639-641.

Cardoso GL, Lomônaco C (2003) Variações fenotípicas e potencial plástico de Eugenia calycina Cambess. (Myrtaceae) em uma área de transição cerrado-vereda. Rev. Bras. Bot. 26:131-140.

Chapin FS, Autumn K, Pugnaire F (1993) Evolution of suites of traits in response to environmental stress. Am. Nat. 142:78-92.

Crandall KA, Bininda-Emonds ORP, Mace GM, Wayne RK (2000) Considering evolutionary processes in conservation biology. Trends Ecol. Evol. 15:290-295.

Delprete PG (1997) Revision and typification of Brazilian Augusta (Rubiaceae, Rondeletieae), with ecological observations on the riverine vegetation of the Cerrado and Atlantic Forest. Brittonia 49:487-497.

Donohue K (1998) Maternal determinants of seed dispersal in Cakile edentula: fruit, plant and site traits. Ecology 79:2771-2778.

Duarte HM, Geßler A, Scarano FR, Franco AC, Mattos EA, Nahm M, Ronnemberg H, Rodrigues PJFP, Zular HLT, Lüttge U (2005) Ecophysiology of six selected shrub species in different plant communities at the periphery of the Atlantic Forest of SE-Brazil. Flora 200:456-476.

Fuzeto AP, Lomônaco C (2000) Potencial plástico de Cabralea canjerana subsp. polytricha (Adr. Juss.) Penn. (Meliaceae) e seu papel na formação de ecótipos 
em áreas de cerrado e vereda, Uberlândia, MG. Rev. Bras. Bot. 23:169-176.

Goulart MF, Lemos Filho JP, Lovato MB (2005) Phenological variation within and among populations of Plathymenia reticulata in Brazilian Cerrado, Atlantic Forest and transitional sites. Ann. Bot. 96: 445-455.

Goulart MF, Lemos Filho JP, Lovato MB (2006) Variability in fruit and seed morphology among and within populations of Plathymenia (Leguminosae Mimosoideae) in areas of the Cerrado, the Atlantic Forest, and transitional sites. Plant Biol. 8:112-119.

Heringer E P (1956) O gênero Plathymenia. Anais da Sociedade Botânica do Brasil 7: 55-64.

Hoffmann WA, Franco AC (2003) Comparative growth analysis of tropical forest and savanna wood plants using phylogenetically independent contrast. J. Ecol. 91:475-484.

Hoffmann WA, Franco AC, Moreira MZ, Haridasan M (2005) Specific leaf area explains differences in leaf traits between congeneric savanna and forest trees. Funct. Ecol. 19:932-940.

Hoffmann WA, Orthen B, Franco AC (2004) Constraints to seedling success of savanna and forest trees across the savanna-forest boundary. Oecologia 140:252-260.

Hogan KP (1996) Ecotypic variation in the physiology of tropical plants. In: Mulkey SS, Chazdon RL, Simth AP (eds), Tropical forest plant ecophysiology, pp.497-530. Chapman \& Hall, New York.

Jump AS, Peñuelas J (2005) Running to stand still: adaptation and the response of plants to rapid climate change. Ecol. Lett. 8:1010-1020.

Kurepin LV, Walton LJ, Reid DM, Pharis RP, Chinnappa CC (2006) Growth and ethylene evolution by shade and sun ecotypes of Stellaria longipes in response to varied light quality and irradiance. Plant Cell Env. 29: 647-652.

Lacerda DR, Acedo MDP, Lemos-Filho JP, and Lovato MB (2001) Genetic diversity and structure of natural populations of Plathymenia reticulata (Mimosoideae), a tropical tree from Brazilian Cerrado. Mol. Ecol. 10:1143-1152

Lacerda DR, Acedo MDP, Lemos Filho JP, Lovato MB (2002) Molecular differentiation of two vicariant neotropical tree species, Plathymenia foliolosa and $P$. reticulata (Mimosoideae), inferred using RAPD markers. Plant Syst. Evol. 235:67-77.

Lacerda DR, Lemos Filho JP, Goulart MF, Ribeiro RA, Lovato MB (2004) Seed dormancy variation in natural populations of two tropical leguminous tree species: Senna multijuga (Caesalpinoideae) and Plathymenia reticulata (Mimosoideae). Seed Sci. Res. 14:127-135.

Lorenzi H (1992) Árvores Brasileiras. Nova Odessa: Editora Plantarum.

Lüttge U, Scarano FR (2004) Ecofisiologia. Rev. Bras. Bot. 27:1-10.

Marquis RJ (1988) Phenological variation in the neotropical understory shrub Piper arieianum: causes and consequences. Ecology 69:1552-1565.

Mittermeier RA, Gil PR, Hoffman M, Pilgrim J, Brooks T, Mittermeier CG, Lamoreux J, da Fonseca GAB (2004) Hotspots Revisited: Earth's Biologically Richest and Most Threatened Terrestrial Ecoregions (Cemex, Conservation International and Agrupacion Sierra Madre, Monterrey, México).

Moritz C (1995) Use of molecular phylogenies for conservation. Phil. Trans. R. Soc. Lond. B. 349:113-118.

Murray BR, Brown AHD, Grace JP (2003) Geographic gradients in seed size among and within perennial Australian Glycine species. Aust. J. Bot. 51:47-56.

Murray BR, Brown AHD, Dickman CR, Crowther MS (2004) Geographical gradients in seed mass in relation to climate. J. Biogeog. 31:379-388.

Nagy ES, Rice KJ (1997) Local adaptation in two subspecies of an annual plant: implications for migration and gene flow. Evolution 51:1079-1089.

Noel F, Machon N, Porcher E (2007) No genetic diversity at molecular markers and strong phenotypic plasticity in populations of Ranunculus nodiflorus, an endangered plant species in France. Ann. Bot. 99:12031212.

Peroni PA (1994) Seed size and dispersal potential of Acer rubrum (Aceraceae) samaras produced by populations in early and late successional environments. Am. J. Bot. 81:1428-1434.

Pigliucci M, Murren CJ, Schlichting CD (2006) Phenotypic plasticity and evolution by genetic assimilation. J. Exp. Biol. 209:2362-2367.

Poorter H, Garnier E (2007) Ecological significance of inherent variation in relative growth rate and its components. In: Pugnaire FI, Valladares F (eds), Functional Plant Ecology, pp. 67-99. CRC Press - 
Taylor and Francis Group: New York.

Ramos ACS, Lemos-Filho JP, Ribeiro RA, Santos FR, Lovato MB (2007) Phylogeography of the tree Hymenaea stigonocarpa (Fabaceae: Caesalpinioideae) and the influence of Quaternary climate changes in the Brazilian Cerrado. Ann. Bot 100: 1219-1228.

Rees M (1996) Evolutionay ecology of seed dormancy and seed size. Phil. Trans. R. Soc. Lond. B 351:12991308.

Reich PB (1995) Phenology of tropical forests: patterns, causes and consequences. Can. J. Bot. 73:164-174.

Seghieri J, Simier S (2002) Variations in phenology of a residual invasive shrub species in Sahelian fallow savannas, south-west Niger. J. Trop. Ecol. 18: 897-912.

Silva Júnior MC (2005) Cem árvores do Cerrado: guia de campo. Rede de sementes do Cerrado: Brasília.

Silva RM, Fernandes GW, Lovato MB (2007) Genetic variation in two Chamaecrista species (Leguminosae), one endangered and narrowly distributed and another widespread in the Serra do Espinhaço, Brazil. Can. J. Bot. 85:629-636.

Smith H, Whitelan GC (1997) The shade avoindance syndrome: multiple responses mediated by multiple phytochromes. Plant Cell Env. 20:840-844.

Stubblebine W, Langenhein JH, Lincoln D (1978) Vegetative response to photoperiod in the tropical leguminous tree Hymenaea courbaril L. Biotropica 10: 18-29.

Valladares F, Sanches-Gomes D, Zavala MA (2006) Quantitative estimation of phenotypic plasticity: bridging the gap between the evolutionary concept and its ecological applications. J. Ecol. 94:1103-1116.

Warwick MC, Lewis GP (2003) Revision of Plathymenia (Leguminosae - Mimosoideae). Edinb. J. Bot. 60:111119.

Yamada, Y. and Suzuki, E. (1999) Comparative morphology and allometry of winged diaspores among the Asian Sterculiaceae. J. Trop. Ecol. 15:619-635. 